\title{
Pengembangan Perangkat Pembelajaran Bangun Datar dengan Pendekatan Open Ended pada Sekolah Menengah Pertama
}

\author{
Asmedy \\ Program Studi Pendidikan Teknologi Informasi, STKIP Yapis Dompu \\ E-mail: asmedy.ntb@gmail.com
}

\begin{abstract}
Article History: Received: 2021-01-05 || Revised: 2021-02-15 || Published: 2021-03-10
Sejarah Artikel : Diterima: 2021-01-05 || Direvisi: 2021-02-15 || Dipublikasi: 2021-03-10
\end{abstract}

\begin{abstract}
This study aims to describe the process of developing a good quality Learning's Equipment for Creative through open-ended aproach and to produce a good quality Learning's Equipment for twodimention figure through open-ended aproach. The criteria of a good quality Learning's Equipment which is developed is appropriate for the procedur of Learning's Equipment and the following five of six categories, in condition the achievement test should valid, reliable, and sensitive; also, the whole process has been taken out: (1) valid, based on the experts assesment, (2) effective for students activity, (3) effective for teacher's ability to manage class learning process, (4) student's response to positive learning, (5) valid, reliable, and sensitive for achievement test, and (6) complete the final test of learning process. This study is the development of Two Dimention Figure Learning's Equipment Research through open-ended aproach at the grade VII of Junior High School. The equipment development model which is used is "Thiangarajan 4-D model" that has been modified. The learning's equipments that are developed are Lesson Plan, Working Sheet, and the achievement test of learning process. Based on descriptive analysis result at the development stage, the researcher concludes that the development of logical learning's equipment though open-ended produces is a good quality because it accomplished: (1) valid based on experts assessment, (2) students activity is active, (3) the teacher ability to manage learning process is effective, (4) the response of student to learning process is positive, (5) the achievement test is vald, reliable, and sensitive, and (6) classical learning result is completed.
\end{abstract}

Keywords: Learning's Equipment, Thiagarajan 4-D Model, Two Dimention Figure, Open-ended Approacah.

\begin{abstract}
Abstrak
Tujuan dari penelitian ini adalah untuk mendeskripsikan proses pengembangan perangkat pembelajaran Bangun Datar dengan pendekatan open-ended yang berkualitas baik dan menghasilkan perangkat pembelajaran Bangun Datar dengan pendekatan open-ended yang berkualitas baik. Kriteria perangkat pembelajaran yang berkualitas baik adalah perangkat pembelajaran yang dikembangkan sesuai dengan prosedur pengembangan perangkat serta memenuhi lima dari enam kategori-kategori berikut dengan catatan THB valid, reliabel, dan sensitif, serta ketuntasan belajar tercapai: (1) valid menurut penilaian pakar, (2) efektif untuk aktivitas siswa, (3) efektif untuk kemampuan guru mengelola pembelajaran, (4) positif untuk respon siswa terhadap pembelajaran, (5) valid, reliabel, dan sensitif untuk THB, dan (6) tuntas untuk hasil belajar. Jenis penelitian ini merupakan penelitian pengembangan perangkat pembelajaran Bangun Datar dengan pendekatan open-ended di kelas VII SMP. Model pengembangan perangkat yang digunakan adalah "model 4-D Thiagarajan" yang telah dimodifikasi. Perangkat pembelajaran yang dikembangkan yaitu Rencana Pelaksanaan Pembelajaran, Lembar Kegiatan Siswa, dan Tes Hasil Belajar. Berdaasarkan hasil analisis deskriptif pada tahap pengembangan diperoleh kesimpulan bahwa perangkat pembelajaran Bangun Datar dengan pendekatan open-ended berkualitas baik, karena memenuhi kategori: (1) valid berdasarkan penilaian ahli, (2) aktivitas siswa efektif, (3) kemampuan guru mengelola pembelajaran efektif, (4) respon siswa terhadap pembelajaran positif (5) valid, reliabel, dan sensitif untuk THB, dan (6) hasil belajar tuntas secara klasikal.
\end{abstract}

Kata kunci: Learning's Equipment, Thiagarajan 4-D Model, Two Dimention Figure, Open-ended Approacah.

\section{PENDAHULUAN}

Peraturan menteri pendidikan nasional tentang Standar Kompetensi Kelulusan Satuan Pendidikan (SKL-SP) untuk SMP dan sederajat, disamping penguasaan dalam materi pelajaran, 
siswa juga harus dibekali dengan kemampuan berpikir logis, kritis, dan kreatif, serta kemampuan bekerjasama. Kompetensi tersebut diperlukan agar peserta didik dapat memiliki kemampuan memperoleh, mengelola, dan memanfaatkan informasi untuk bertahan hidup pada keadaan yang selalu berubah, tidak pasti, dan kompetitif. Usaha untuk meningkatkan kualitas pendidikan, khususnya pendidikan matematika telah banyak dilakukan, bahkan terus menerus diupayakan, namun mutu pendidikan yang dicapai belum sesuai dengan harapan yang diinginkan. Berdasarkan hasil wawancara dengan beberapa guru yang sudah berpengalaman menjadi guru matematika, khususnya guru SMP Negeri 3 Donggo, bahwa dalam mempelajari matematika diharapkan siswa tidak hanya mengingat, memahami, dan menerapkan saja, akan tetapi siswa diharapkan juga dapat menganalisis dan mengevaluasi informasi. Karena itu, dalam pembelajaran matematika guru tidak mentransfer ilmu kepada siswa tetapi bagaimana guru mengarahkan siswa untuk membangun pengetahuan baru sesuai dengan pemikiran mereka sendiri.

Menurut Soejadi (2000: 45), pendidikan matematika seharusnya memperhatikan dua tujuan, yaitu (1) tujuan yang bersifat formal, yaitu menekankan pada penataan nalar serta pembentukkan kepribadian, dan (2) tujuan yang bersifat material, yaitu menekankan pada penerapan matematika dan keterampilan matematika. Tidak mudah merancang pembelajaran yang dapat menuntaskan hasil belajar dan penalaran logis siswa. Banyak sekali kendala yang harus dihadapi. Salah satu kendalanya adalah banyak guru yang menganggap matematika merupakan ilmu pasti, tetapi pada dasarnya matematika merupakan ilmu untuk berpikir kritis. Dengan demikian apabila pengajar tidak mengerti akan hal tersebut dikhawatirkan kemampuan berpikir kreatif siswa tidak berkembang secara utuh.

Terkait dengan realitas yang terjadi sekarang, pengajar perlu memikirkan bagaimana mengembangkan perangkat pembelajaran yang bertujuan mengembangkan semaksimal mungkin penalaran logis siswa. Salah satu hal yang paling penting adalah perlunya memberikan kesempatan siswa untuk berpikir dengan bebas sesuai dengan minat dan kemampuan. Sehingga dengan pendekatan open-ended, aktivitas kelas akan penuh dengan ide-ide matematika dan pada akhirnya dapat menuntaskan hasil belajar dan memacu berkembangnya kemampuan berpikir kreatif siswa. Usaha untuk meningkatkan kualitas pendidikan, khususnya pendidikan matematika telah banyak dilakukan, bahkan terus menerus diupayakan, namun mutu pendidikan yang dicapai belum sesuai dengan harapan yang diinginkan. Berdasarkan hasil wawancara dengan beberapa guru yang sudah berpengalaman menjadi guru matematika, khususnya guru SMP di Bima Dompu, bahwa dalam mempelajari matematika diharapkan siswa tidak hanya mengingat, memahami, dan menerapkan saja, akan tetapi siswa diharapkan juga dapat menganalisis dan mengevaluasi informasi. Karena itu, dalam pembelajaran matematika guru tidak mentransfer ilmu kepada siswa tetapi bagaimana guru mengarahkan siswa untuk membangun pengetahuan baru sesuai dengan pemikiran mereka sendiri.

Kenyataan di lapangan menunjukkan bahwa pengajaran matematika yang dilakukan di sekolah, khususnya di SMP Negeri 3 Donggo,masih berjalan secara konvensional; yaitu, mengikuti urutan sajian mulai diajarkan definisi, teorema, diberikan contoh, dan terakhir diberikan latihan menyelesaikan soal-soal. Cara penyajian seperti ini menimbulkan kesan bahwa guru cenderung mendominasi proses belajar mengajar, dan siswa kadang-kadang tidak memahami apa yang mereka pelajari. Yuwono (2001) menyebutkan bahwa pengajaran matematika secara konvensional mengakibatkan siswa hanya bekerja secara prosedural dan memahami matematika tanpa penalaran. Selain itu, salah satu keluhan yang sering ditemukan dalam dunia pendidikan matematika adalah kurangnya keterkaitan matematika di sekolah dengan dunia nyata dan kehidupan sehari-hari siswa.

Tidak mudah merancang pembelajaran yang dapat menuntaskan hasil belajar dan kreativitas siswa. Banyak sekali kendala yang harus dihadapi. Salah satu kendalanya adalah banyak guru yang menganggap matematika merupakan ilmu pasti, tetapi pada dasarnya matematika merupakan ilmu 
untuk berpikir kreatif. Dengan demikian apabila pengajar tidak mengerti akan hal tersebut dikhawatirkan kemampuan berpikir kreatif siswa tidak berkembang secara utuh. Morgan (dalam Ratumanan, 2004:1) menyatakan bahwa, belajar adalah perubahan tingkah laku yang relatif tetap dan terjadi sebagai hasil latihan atau pengalaman. Dalam proses belajar, pengetahuan yang diperoleh bisa saja punah atau berkurang jika tidak diberi penguatan atau perhatian. Oleh karena itu, dalam proses belajar dibutuhkan latihan berulang-ulang.

Pembelajaran matematika dalam penelitian ini dapat didefinisikan sebagai suatu proses membangun pemahaman siswa tentang pengetahuan keterampilan, konsep, prinsip atau aturan, serta pengambilan kesimpulan logis terhadap materi matematika melalui proses internalisasi. Pembelajaran kooperatif adalah pembelajaran yang berdasarkan teori konstruktivis. Pembelajaran ini muncul dari anggapan bahwa siswa akan lebih mudah menemukan dan memahami konsep jika mereka berinteraksi dengan orang lain terutama dengan temannya. Pembelajaran kooperatif merupakan suatu strategi pembelajaran yang melibatkan siswa belajar secara berkolaborasi untuk mencapai tujuan bersama (Eggen and Kauchak, 1996: 279). Trianto (2007: 44) menyatakan bahwa pembelajaran kooperatif dapat meningkatkan kinerja siswa dalam tugas-tugas akademik, unggul dalam membantu siswa dalam memahami konsep-konsep yang sulit, membantu siswa dalam menumbuhkan kemampuan berpikir kritis dan memberikan banyak keuntungan baik siswa yang berkemampuan tinggi maupun rendah.

Pembelajaran kooperatif memiliki ciri yaitu adanya struktur tugas, tujuan dan penghargaan kooperatif. Siswa yang bekerja dalam situasi pembelajaran kooperatif didorong dan dikehendaki untuk bekerja sama pada suatu tugas, dan mereka harus mengkoordinasikan usahanya untuk menyelesaikan tugasnya. Mereka akan diberikan penghargaan seandainya mereka berhasil menjadi kelompok terbaik (Ibrahim, 2005: 2). pembelajaran kooperatif adalah pembelajaran yang dapat dipakai untuk mendidik siswa, sehingga disamping tujuan akademik tercapai, siswa juga memperoleh keterampilan sosial dan memahami keanekaragaman dari lingkungan sekitar. Materi bangun datar yang di bahas dalam penelitian ini antara lain, keliling dan luas persegi, persegi panjan, segitiga, jajar genjang, laying-layang, belah ketupat, trapezium, dan lingkaran.

Tabel 1. Fase-fase Model Pembelajaran Matematika dengan pendekatan open-ended

\begin{tabular}{lll}
\hline Fase-fase & Aktivitas Guru & Aktivitas Siswa \\
\hline \multirow{2}{*}{ Orientasi } & $\begin{array}{l}\text { Guru memotivasi siswa dengan soal yang } \\
\text { berkaitan dengan kehidupan sehari-hari } \\
\text { siswa, juga menjelaskan tujuan yang akan } \\
\text { dicapai setelah pembelajaran. }\end{array}$ & $\begin{array}{l}\text { Siswa mendengar penjelasan guru, } \\
\text { menjawab atau mengerjakan soal } \\
\text { jika ada pertanyaan atau soal yang } \\
\text { disampaikan oleh guru. }\end{array}$ \\
\hline & $\begin{array}{l}\text { Guru memberikan penjelasan umum } \\
\text { tentang materi yang akan dipelajari siswa. }\end{array}$ & \\
& $\begin{array}{l}\text { Penjelasan umum ini dimaksudkan agar } \\
\text { siswa dalam menyelesaikan soal yang }\end{array}$ & \\
Pembekalan & bersifat terbuka yang akan diselesaikan \\
dan & pada fase berikutnya tidak dalam keadaan \\
penyajian & "kosong". Apabila materi itu bukan materi & $\begin{array}{l}\text { guru dan mencatat soal yang } \\
\text { diberikan atau menerima lembaran } \\
\text { soal jika soal sudah dalam bentuk }\end{array}$ \\
terbuka & baru, artinya siswa sudah mempunyai & lembaran. \\
& $\begin{array}{l}\text { konsep-konsep dasar matematika, } \\
\text { pembekalan bisa berupa permainan untuk } \\
\text { membekali siswa dalam menyelesaikan }\end{array}$ & \\
& soal terbuka yang akan diberikan. & \\
\hline
\end{tabular}


Pengerjaan

soal terbuka secara individu
Siswa secara individu mengerjakan soal harus mereka selesaikan. Untuk menyelesaika soal, siswa dibagikan lembar jawaban dan buram yang nantinya baik lembar jawaban maupun buram harus dikumpulkan.

$\begin{array}{ll}\text { Diskusi } & \text { Guru meminta siswa bergabung dengan } \\ \text { kelompok } & \text { kelompok untuk berdiskusi menyelesaikan } \\ \text { tentang soal } & \text { tugas kelompok. (soal yang didiskusikan } \\ \text { terbuka } & \text { dalam kelompok sama dengan tugas } \\ & \text { individu pada fase sebelumnya). }\end{array}$

Presentasi

hasil

diskusi

kelompok
Guru mengambil hasil pekerjaan siswa setelah habis waktu yang diberikan,
Siswa secara kelompok berdiskusi untuk menyelesaikan tugas kelompok.
- Siswa mempresentasikan hasil diskusi kelompoknya.

- Siswa yang lain dari tiap kelompok harus menanggapi atau bertanya kepada siswa yang presentasi.

$\begin{array}{lll} & \text { Guru bersama siswa menyimpulkan ide } & \\ \text { atau konsep yang telah diperoleh pada hari } & \\ \text { itu. Teknik yang digunakan seperti guru } & \text { Siswa mencatat kesimpulan yang } \\ \text { memberikan pertanyaan-pertanyaan yang } & \text { diperoleh. } \\ \text { merangsang siswa untuk memperoleh } & \\ \text { poin-poin penting yang diharapkan. } & \end{array}$

Dikutip dari Khabibah (2006).

Perangkat pembelajaran adalah sekumpulan sumber belajar yang memungkinkan guru dan siswa melakukan kegiatan pembelajaran. Sumber-sumber belajar yang dikembangkan dalam penelitian ini terdiri dari: Rencana Pembelajaran, Lembar Kerja Siswa, dan Tes Hasil Belajar topik Bangun Datar matematika dengan pendekatan open-ended.

\section{METODE PENELITIAN}

Pengembangan perangkat pembelajaran yang dilakukan dalam penelitian ini menggunakan model pengembangan Thiagarajan (Thiagarajan, Semmel dan Semmel, 1974) yang juga dikenal dengan Four - D Model atau model 4-D. Model ini terdiri atas empat tahap, yaitu: pendefinisian (Define), perancangan (Design), pengembangan (Develop), dan penyebaran (Disseminate).

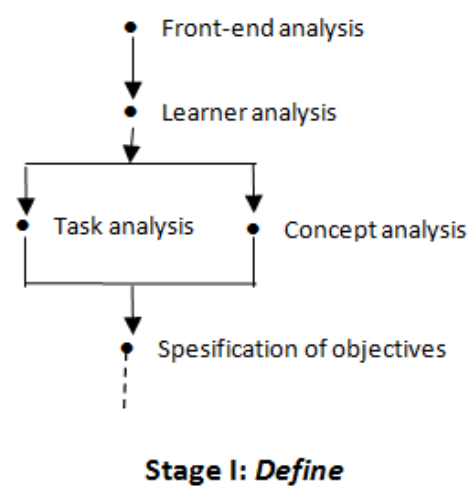

Stage I: Define

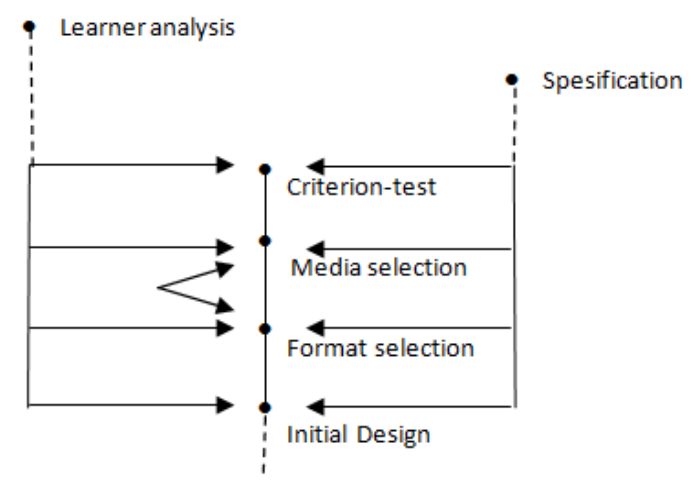

Stage II: Design 


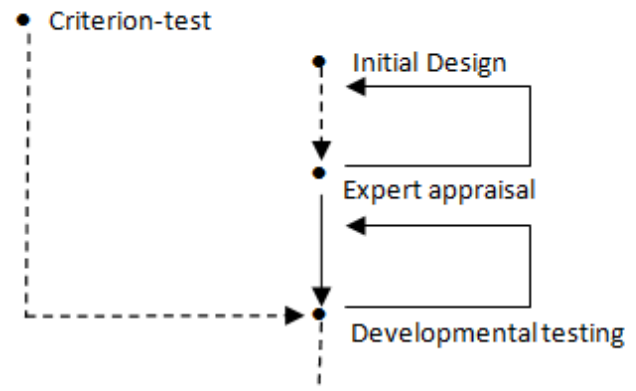

Stage III: Develop

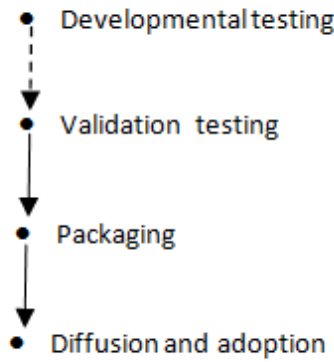

Stage IV: Disseminate

Gambar 1. Skema Model Pengembangan 4 -D (Thiagarajan, Semmel dan Semmel, 1974)

Berdasarkan pertanyaan penelitian yang telah dikemukakan pada bab sebelumnya, penelitian ini digolongkan ke dalam jenis penelitian pengembangan. Adapun yang akan dikembangkan dalam penelitian ini adalah perangkat pembelajaran dan instrumen. Perangkat pembelajaran yang dikembangkan meliputi: Rencana Pelaksanaan Pembelajaran, Lembar Kerja Siswa, dan Tes Hasil Belajar untuk materi Bangun Datar dengan pendekatan open-ended di kelas VII SMPN 3 Donggo yang bertujuan untuk menuntaskan hasil belajar siswa. Instrumen dalam penelitian ini antara lain: Lembar Validasi Perangkat Pembelajaran, Lembar Observasi Aktivitas Siswa, Lembar Observasi Keterlaksanaan Perangkat Pembelajaran serta Angket Respon Siswa.

Pada tahap pengembangan perangkat dalam penelitian ini dilakukan uji coba perangkat pembelajaran di kelas. Sebagai subjek penelitian dalam uji coba perangkat pembelajaran adalah siswa kelas VII SMP Negeri 3 Donggo semester genap tahun pelajaran 2016/2017. Pengambilan subjek dilakukan secara acak dari tujuh kelas paralel selain kelas unggulan untuk memilih satu kelas dari empat kelas yang memiliki kemampuan yang sama (berdasarkan keterangan guru). Kemudian untuk keperluan analisis validitas butir tes, analisis reliabilitas tes, dan analisis sensitivitas butir tes. Sedangkan uji keterbacaan dilakukan pada tiga siswa yang memiliki kemampuan berbeda.

Model pengembangan yang akan digunakan untuk mengembangkan perangkat pembelajaran dalam penelitian ini adalah model Thiagarajan (1974) yang dikenal dengan Four-D Models (Model 4-D). Namun, dalam pelaksanaannya hanya sampai pada tahap III, yaitu tahap pengembangan (develop). Sedangkan tahap penyebaran (disseminate) tidak dilakukan karena setelah tahap pengembangan sudah dihasilkan perangkat yang berkualitas baik sesuai dengan tujuan penelitian. Selain itu, dalam pelaksanaan model pengembangan ini dilakukan beberapa modifikasi. Adapun modifikasi-modifikasi yang dilakukan beserta alasan memodifikasi model pengembangan perangkat adalah sebagai berikut:

1. Istilah analisis konsep diganti menjadi analisis materi. Karena materi memiliki cakupan yang lebih luas dari pada konsep.

2. Analisis materi dan analisis tugas tidak dilaksanakan secara paralel tetapi dilakukan secara berurutan. Sebab, materi dalam matematika sudah terstruktur sehingga urutan tugas bergantung pada urutan konsep. Selain itu, pelaksanaan analisis tugas setelah analisis materi memungkinkan pembuatan tugas yang mencakup beberapa materi.

3. Sebelum tahapan uji coba terlebih dahulu dilaksanakan uji keterbacaan agar perangkat yang diujicobakan lebih mudah dipahami oleh siswa.

Model 4-D dipilih karena peneliti hanya akan mengembangkan perangkat pembelajaran dan bukan sistem pembelajaran secara keseluruhan. Selain itu, dari beberapa model pengembangan 
yang ada, model pengembangan 4-D lebih sistematis dan lebih terarahkan untuk pengembangan perangkat pembelajaran.

\section{HASIL DAN PEMBAHASAN}

Hasil belajar yang ditunjukkan oleh nilai postes pada saat uji coba adalah sebagai berikut:

Tabel 2. Nilai tes hasil belajar

\begin{tabular}{ll}
\hline Nilai & Postes \\
\hline Tertinggi & 30 \\
\hline Terendah & 14 \\
\hline Rata-rata & 22,35 \\
\hline
\end{tabular}

Seperti yang telah diuraikan pada Bab III, bahwa belajar siswa dikatakan tuntas secara individual, jika skor postes yang diperoleh paling sedikit $70 \%$ dari skor tertinggi, yaitu 30 . Sedangkan suatu kelompok (kelas) dikatakan tuntas belajarnya secara klasikal jika 85\% siswa tuntas secara individual. Ketuntasan belajar siswa baik secara individual maupun secara klasikal ditunjukkan dalam Tabel berikut:

Tabel 3. Ketuntasan hasil belajar

\begin{tabular}{ll}
\hline \multicolumn{1}{c}{ Postes } & \multicolumn{1}{c}{ Uji coba } \\
\hline Banyaknya siswa yang tuntas secara individu & 23 siswa atau $85 \%$ \\
\hline Banyaknya siswa yang tidak tuntas secara individu & 3 siswa atau $15 \%$ \\
\hline Ketuntasan belajar secara klasikal & Tuntas \\
\hline
\end{tabular}

Beberapa hal yang dapat dicatat dalam penelitian ini berdasarkan temuan pada saat validasi ahli dan uji coba lapangan, diuraikan sebagai berikut:

Hasil penilaian ahli/validator menunjukkan bahwa, perangkat pembelajaran yang terdiri dari: RPP, LKS, dan THB ditinjau dari indikator format, bahasa, isi, dan/atau ilustrasi dikategorikan baik. Hal ini ditunjukkan dengan rata-rata skor penilaian ahli terhadap RPP, LKS, dan THB lebih dari 3,50. Secara umum, perangkat pembelajaran Bangun Datar dengan pendekatan open-ended di SMP yang dikembangkan berada pada kategori "sangat baik" dan dapat digunakan dengan sedikit revisi. Jadi, secara keseluruhan perangkat pembelajaran Bangun Datar dengan pendekatan open-ended di SMP baik menurut penilaian ahli, Berdasarkan kategori kemampuan guru mengelola pembelajaran seperti yang diuraikan pada Bab III, hasil analisis data setiap aspek kemampuan guru mengelola pembelajaran yang diamati/dinilai untuk 4 pertemuan mengindikasikan bahwa pembelajaran efektif. Hal ini ditunjukkan dengan rata-rata skor setiap aspek kemampuan guru mengelola pembelajaran mencapai kategori minimal baik.

Pembelajaran Bangun Datar dengan pendekatan open-ended di VII SMP 3 Donggo mengharuskan siswa untuk aktif dalam pembelajaran. Sehingga, dominasi guru dapat berkurang. Hal ini sejalan dengan Teori Konstruktivis dimana teori ini menganjurkan agar siswa lebih berperan aktif dalam pembelajaran atau yang lebih dikenal dengan pembelajaran yang berpusat pada siswa. Hasil analisis data aktivitas siswa menunjukkan bahwa, persentase aktivitas siswa dari setiap aspek yang diamati selama 4 pertemuan sesuai dengan alokasi waktu dalam RPP dan sesuai dengan kriteria waktu ideal, Berdasarkan kriteria keefektifan aktivitas siswa menunjukkan bahwa Aspek ke-1 tentang "Memperhatikan/mencatat/bertanya/menjawab penjelasan atau pertanyaan dari guru saat orientasi dan pembekalan" untuk semua RPP berada pada kriteria waktu ideal. Aspek ke-2 tentang "menyelesaikan LKS secara individu" untuk semua RPP berada pada kriteria waktu ideal. Aspek ke-3 tentang "menyelesaikan LKS melalui diskusi kelompok" untuk semua RPP berada 
pada kriteria waktu ideal. Aspek ke-4 tentang "berperan serta dalam kegiatan presentasi" untuk semua RPP berada pada kriteria waktu ideal. Aspek ke-5 tentang "mengikuti penarikan kesimpulan" untuk semua RPP berada pada kriteria waktu ideal. Aspek ke- 6 tentang "prilaku yang tidak relevan" untuk semua RPP berada pada kriteria waktu ideal. Berdasarkan data di atas dapat disimpulkan bahwa aktivitas siswa dikategorikan "efektif".

Respon siswa terhadap pembelajaran, hasil analisis data respon siswa terhadap komponen dan kegiatan pembelajaran Bangun Datar dengan pendekatan open-ended menunjukkan lebih dari 70\% siswa memberikan respon dengan kategori "positif" untuk tiap-tiap aspek. Hasil analisis validitas butir tes, reliabilitas tes, dan sensitivitas butir tes menunjukkan bahwa semua butir tes hasil belajar topik Bangun Datar memiliki validitas cukup dan tinggi, hal ini sejalan dengan yang dikemukakan Arikunto bahwa suatu butir dinyatakan valid jika koefisien validitas butir tersebut diinterpretasikan minimal cukup. Reliabilitas tes hasil belajar termasuk dalam kategori tinggi, dan semua butir tes sensitif terhadap pembelajaran. hal ini juga sejalan dengan yang dikemukakan Ratumanan dan Laurens bahwa suatu tes ddinyatakan reliabel jika koefisien reliabilitas tes tersebut diinterpretasikan minimal cukup dan suatu butir tes dikatakan sensitif apabila indeks sensitivitasnya berada antara 0,00 dan 1,00. Sehingga THB dikategorikan "baik". Berdasarkan kriteria ketuntasan hasil belajar yang telah diuraikan pada Bab III, ketuntasan belajar siswa secara individual mencapai 23 siswa atau 85\% siswa tuntas secara individual. Oleh karena itu, ketuntasan belajar siswa dinyatakan "tuntas".

Berdasarkan pembahasan di atas dan apa yang telah diuraikan pada Bab III, perangkat pembelajaran ini dapat disimpulkan memenuhi kategori baik. Sebab keenam syarat terpenuhi: (a) valid berdasarkan penilaian ahli, (b) kemampuan guru dalam mengelola pembelajaran efektif, (c) aktifitas siswa efektif, (d) respon siswa positif terhadap pembelajaran, dan (e) THB valid, reliable, dan sensitive, (f) hasil belajar siswa secara klasikal tuntas. Oleh karena itu, perangkat pembelajaran Bangun Datar dengan pendekatan open-ended memenuhi kategori "baik".

\section{SIMPULAN DAN SARAN}

\section{A. Simpulan}

Berdasarkan tujuan dan hasil penelitian dapat disimpulkan sebagai berikut:

1. Prosedur pengembangan perangkat pembelajaran Bangun Datar dengan pendekatan openended menggunakan model 4-D yang dimodifikasi menjadi tiga tahap sesuai dengan tujuan penelitian; yaitu: (1) Tahap Pendefinisian. Kegiatan yang dilakukan dalam tahap ini adalah analisis awal-akhir, analisis siswa, analisis konsep, analisis tugas, dan spesifikasi tujuan pembelajaran; (2) Tahap Perancangan. Hasil kegiatan pada tahap ini yaitu rancangan awal perangkat pembelajaran berupa RPP, LKS, dan THB; (3) Tahap Pengembangan. Hasil kegiatan pada tahap ini yaitu Draft II, uji keterbacaan menghasilkan Draft III, dan kegiatan akhir yaitu uji coba Draft III, data hasil uji coba dianalisis dan dapat disimpulkan bahwa, perangkat pembelajaran berada pada kategori "baik".

2. Berdasarkan hasil analisis deskriptif, perangkat pembelajaran Bangun Datar dengan pendekatan open-ended diketegorikan baik. Karena keenam kriteria perangkat pembelajaran yang baik terpenuhi, yaitu: (1) Valid menurut validator, (2) Efektif untuk kemampuan guru mengelola pembelajaran, (3) Efektif untuk aktivitas siswa dalam pembelajaran, (4) Positif untuk respon siswa terhadap pembelajaran, (5) Valid, reliabel, dan sensitif untuk THB, dan (6) Ketuntasan belajar secara klasikal tercapai.

\section{B. Saran}

Berdasarkan hasil penelitian, dikemukakan saran-saran sebagai berikut:

1. Prosedur pengembangan perangkat pembelajaran Bangun Datar dengan pendekatan openended menggunakan model 4-D, dapat menghasilkan perangkat pembelajaran yang baik. Maka 
peneliti menyarankan agar perangkat yang dikembangkan ini digunakan sebagai alternatif perangkat pembelajaran bagi siswa SMP.

2. Mengingat perangkat yang dikembangkan ini belum diketahui efektifitasnya untuk jumlah subjek yang banyak, maka peneliti juga menyarankan agar peneliti-peneliti lain mengujicobakan perangkat hasil pengembangan ini pada subjek lain yang lebih besar untuk memperoleh informasi tentang efektivitas perangkat.

3. Selain RPP, LKS dan THB juga harus mengembangkan Buku Siswa sebagai pegangan siswa saat proses belajar mengajar.

4. Mencantumkan pemberian materi pada RPP yang dikembangkan.

5. Pada THB seharusnya juga memuat aspek kreatifitas sebagai salah satu tujuan pembelajaran dengan pendekatan open-ended.

\section{DAFTAR RUJUKAN}

Arikunto, S. 2005. Dasar-dasar Evaluasi Pendidikan Matematika. Edisi Revisi. Jakarta: Bumi Aksara.

Asmedy. (2018). Pengembangan Perangkat Pembelajaran Bangun Datar dengan Pendekatan Open Ended. JIIP - Jurnal Ilmiah Ilmu Pendidikan, 1(2), 66-72. Retrieved from http://jiip.stkipyapisdompu.ac.id/jiip/index.php/IIIP/article/view/11

Asmedy. (2020). Perbandingan Hasil Belajar Connected Mathematics Project (CMP) dengan Pembelajaran Konvensional Pada Pokok Bahasan Geometri. JIIP - Jurnal Ilmiah Ilmu Pendidikan, 3(1), 456-464. Retrieved from http://iiip.stkipyapisdompu.ac.id/iiip/index.php/IIIP/article/view/131

Hudojo, H. 2003. Pengembangan Kurikulum dan Pembelajaran Matematika. Edisi Revisi. Technical Cooperation Project for Development of Science and Mathematics Teaching For Primary and Secondary Education In Indonesia (IMSTEP).

Khabibah, Siti. 2006. Pengembangan Model Pembelajaran Matematika dengan Soal Terbuka untuk Meningkatkan Kreaktivitas Siswa Sekolah Dasar. Disertasi. Surabaya: Program Pascasarjana UNESA.

Mahlobo. Open-Ended Approach to Teaching and Learning of High School Mathematics. Mathematics Departement, Faculty of Applied and Computer Sciences Vaal University of Technology: South Africa.

Nur, Mohamad. 2011. Model Pembelajaran Kooperatif. UNESA Penerbit Pusat Sains dan Matematika sekolah: Surabaya.

Ratumanan, Tanwey G, dan Laurens, Theresia. 2003. Evaluasi Hasil Belajar yang Relevan dengan Kurikulum Berbasis Kompetensi. YP3IT dan Unesa University Press.

Ratumanan, Tanwey G. 2002. Belajar dan Pembelajaran. Unesa University Press. Surabaya.

Sawada, Toshio. 1997. Developing Lesson Plan. Bahan Kuliah Pembelajaran Matematika IB.

Shimada, Shigeru. 1977. The Open-Ended Approach: A New Proposal for Teaching Mathematics. National Council of Teachers of Mathematics (NCTM). Virginia.

Simangunsong, W. 1991. Matematika Dasar. Penerbit Erlangga: Jakarta.

Slavin, Robert E. 2008. Cooperative Learning: Teory, Riset, dan Praktik. Diterjemahkan oleh Nurulita. Penerbit Nusa Media: Bandung. 
Soedjadi, R. 2007. Masalah Kontekstual sebagai Batu Sendi Matematika Sekolah. Penerbit Pusat Sains dan Matematika Sekolah UNESA: Surabaya.

Suherman, Erman; dkk. 2003. Strategi Pembelajaran Matematika Kontemporer. Universitas Pendidikan Indonesia: Bandung.

Suparno, P. 1996. Filsafat Konstruktivisme dalam Pendidikan. Boston: Kanisius.

Thiagarajan, S., Semmel, D.S., dan Semmel, M.I. 1974. Instructional Development for Training Teacher of Exceptional Children. Minnesota: University of Minnesota.

Trianto. 2007. Model-model Pembelajaran Inovatif Berorientasi Konstruktivistik. Jakarta: Prestasi Pustaka Publisher.

Trianto. 2009. Mendesain Model Pembelajaran Inovatif dan Progresif: Konsep, Landasan, dan Implementasinya pada Kurikulum Tingkat Satuan Pendidikan (KTSP). Jakarta: Kencana Pranada Media Group. 